\title{
FORTY-FIRST ANNUAL LIST OF PAPERS
}

READ BEFORE THE AMERICAN MATHEMATICAL SOCIETY AND SUBSEQUENTLY PUBLISHED, INCLUDING REFERENCES TO THE PLACES OF PUBLICATION

Adams, C. R. On summability of double series. Read Sept. 8, 1931. Transactions of this Society, vol. 34, No. 2, pp. 215-230; April, 1932.

- Note on multiple Dirichlet and multiple factorial series. Read Sept. 9, 1931. Annals of Mathematics, (2), vol. 33, No. 3, pp. 406-412; July, 1932.

AgNew, R. P. On double orthogonal series. Read Dec. 30, 1930, and Feb. 28, 1931. Proceedings of the London Mathematical Society, (2), vol. 33, No. 6, pp. 420-434; March, 1932.

- On equivalence of methods of evaluation of sequences. Read April 3, 1931. Tôhoku Mathematical Journal, vol. 35, No. 2, pp. 244-252; May, 1932.

- On deferred Cesàro means. Read Sept. 10, 1931. Annals of Mathematics, (2), vol. 33, No. 3, pp. 413-421; July, 1932.

- On summability of double sequences, Read March 26, 1932. American Journal of Mathematics, vol. 54, No. 4, pp. 648-656; Oct., 1932.

Albert, A. A. On the construction of cyclic algebras with a given exponent. Read Sept. 9, 1931. American Journal of Mathematics, vol. 54, No. 1, pp. 1-13; Jan., 1932.

- Normal division algebras of degree $2^{e}$ and pure Riemann matrices. Read Dec. 28, 1931. Annals of Mathematics, (2), vol. 33, No. 2, pp. 311-318; April, 1932.

- Normal division algebras of degree four over an algebraic field. Read Oct. 31, 1931. Transactions of this Society, vol. 34, No. 2, pp. 363-372; April, 1932.

- A construction of non-cyclic normal division algebras. Read April 9, 1932. This Bulletin, vol. 38, No. 6, pp. 449-456; June, 1932.

- On normal simple algebras. Read April 9, 1932. Transactions of this Society, vol. 34, No. 3, pp. 620-625; July, 1932.

- A note on normal division algebras of order sixteen. Read Aug. 31, 1932. This Bulletin, vol. 38, No. 10, pp. 703-706; Oct., 1932.

Albert, A. A., and HASSE, H. A determination of all normal division algebras over an algebraic number field. Read April 9, 1932. These Transactions, vol. 34, No. 3, pp. 722-726; July, 1932.

Alexander, J. W., and Cohen, L. W. A classification of the homology groups of compact spaces. Read April 4, 1931. Annals of Mathematics, (2), vol. 33, No. 3, pp. 538-566; July, 1932.

Altshiller-Court, N. On the isodynamic points of four spheres. Read Dec. 28, 1931. American Mathematical Monthly, vol. 39, No. 4, pp. 193-199; April, 1932.

Ayres, W. L. Note on a property of continuous arcs. Read Sept. 9, 1931. Proceedings of the Cambridge Philosophical Society, vol. 27, No. 4, pp. 543-545; Oct., 1931. 
- On a certain neighborhood property. Read Nov. 28, 1931. Fundamenta Mathematicae, vol. 19, pp. 72-78; 1932.

— On joining finite subsets of a Peano space by arcs and simple closed curves. Read Aug. 30, 1929. Fundamenta Mathematicae, vol. 19, pp. 79$91 ; 1932$.

BARNETT, I. A., and NATHAN, D. S. Sphere geometry and the conformal group in function space. Read Nov. 30, 1929, and April 8, 1932. Proceedings of the National Academy of Sciences, vol. 18, No. 5, pp. 400-403; May, 1932.

Bartky, W., and MAcMillaN, W. D. Permanent configurations in the problem of four bodies. Read Sept. 2, 1932. Transactions of this Society, vol. 34, No. 4, pp. 838-875; Oct., 1932.

BAsoco, M. A. On the Fourier series expansions of certain Jacobian elliptic functions. Read Dec. 30, 1930. Tôhoku Mathematical Journal, vol. 35, No. 1, pp. 35-42; Jan., 1932.

- Note on certain theta constants. Read Dec. 30, 1930. Tôhoku Mathematical Journal, vol. 35, No. 1, pp. 60-63; Jan., 1932.

- Fourier developments for certain pseudo-periodic functions in two variables. Read Nov. 28, 1931. American Journal of Mathematics, vol. 54, No. 2, pp. 242-252; April, 1932.

- On the trigonometric developments of certain doubly periodic functions of the second kind. Read April 8, 1932. This Bulletin, vol. 38, No. 8, pp. 560-568; Aug., 1932.

Bateman, H. Relations between confluent hypergeometric functions. Read Sept. 9, 1931. Proceedings of the National Academy of Sciences, vol. 17, No. 12, pp. 689-690; Dec., 1931.

BATEN, W. D. A remainder for the Euler-Maclaurin summation formula in two independent variables. Read Dec. 31, 1930. American Journal of Mathematics, vol. 54, No. 2, pp. 265-275; April, 1932.

BeLL, C. On triangles in- and circumscribed to two cubic curves. Read Nov. 29, 1930. Tôhoku Mathematical Journal, vol. 36, No. 1, pp. 34-40; Aug., 1932.

BeLl, E. T. A theory of certain fields of points. Read June 20, 1930. Bulletin de la Societé Mathématique de Grèce, vol. 12, No. 2, pp. 98-108; 1931.

- On the real multiplication of elliptic functions. Read Nov. 28, 1931. Annals of Mathematics, (2), vol. 33, No. 2, pp. 207-213; April, 1932.

Bernstein, B. A. Note on the condition that a Boolean equation have a unique solution. Read April 11, 1931. American Journal of Mathematics, vol. 54, No. 2, pp. 417-418; April, 1932.

— On proposition *4.78 of Principia Mathematica. Read Oct. 31, 1931. This Bulletin, vol. 38, No. 6, pp. 388-391; June, 1932.

- Relation of Whitehead and Russell's theory of deduction to the Boolean logic of propositions. Read June 20, 1929. This Bulletin, vol. 38, No. 8, pp. 589-593; Aug., 1932.

- On unit-zero Boolean representations of operations and relations. Read April 11, 1931. This Bulletin, vol. 38, No. 10, pp. 707-712; Oct., 1932.

- On Nicod's reduction in the number of primitives of logic. Read Aug. 30, 1932. Proceedings of the Cambridge Philosophical Society, vol. 28, No. 4, pp. 427-432; Oct., 1932. 
Bernstein, B. A., and Debely, N. A practical method for the modular representation of finite operations and relations. Read April 5, 1930. This Bulletin, vol. 38, No. 2, pp. 110-114; Feb., 1932.

Birkhoff, G. D. Probability and physical systems. Read Dec. 29, 1931. This Bulletin, vol. 38, No. 6, pp. 361-379; June, 1932.

BLACK, A. H. Types of involutorial space transformations associated with certain rational curves. Read Sept. 2, 1932. Transactions of this Society, vol. 34, No. 4, pp. 795-810; Oct., 1932.

Bliss, G. A. The calculus of variations and the quantum theory. Read Dec. 29, 1931. This Bulletin, vol. 38, No. 4, pp. 201-224; April, 1932.

Bliss, G. A., and SchoenberG, I. J. On the derivation of necessary conditions for the problem of Bolza. Read Oct. 29, 1932. This Bulletin, vol. 38, No. 12, pp. 858-864; Dec., 1932.

Blumenthal, L. M. A complete characterization of proper pseudo $d$-cyclic sets of points. Read Dec. 28, 1931. American Journal of Mathematics, vol. 54, No. 2, pp. 387-396; April, 1932.

— Concerning regular pseudo $d$-cyclic sets. Read March 25, 1932. American Journal of Mathematics, vol. 54, No. 4, pp. 729-738; Oct., 1932.

Botsford, J. L., and Michal, A. D. An extension of the new Einstein geometry. Read April 9, 1932. Proceedings of the National Academy of Sciences, vol. 18, No. 8, pp. 554-558; Aug., 1932.

- Simultaneous differential invariants of an affine connection and a general linear connection. Read Sept. 2, 1932. Proceedings of the National Academy of Sciences, vol. 18, No. 8, pp. 558-562; Aug., 1932.

BRIDGMAN, P. W. Statistical mechanics and the second law of thermodynamics. Read Dec. 29, 1931. This Bulletin, vol. 38, No. 4, pp. 225-245; April, 1932. Science, new ser., vol. 75, No. 1947, pp. 419-428; April 22, 1932.

Brown, A. B. Topological invariance of sub-complexes of singularities. Read June 13, 1931. American Journal of Mathematics, vol. 54, No. 1, pp. 117122; Jan., 1932.

- Group invariants and torsion coefficients. Read Sept. 9, 1931. Annals of Mathematics, (2), vol. 33, No. 2, pp. 373-376; April, 1932.

- On Morse's duality relations for manifolds. Read March 25, 1932. American Journal of Mathematics, vol. 54, No. 4, pp. 692-698; Oct., 1932.

Brown, A. B., and Koopman, B. O. On the covering of analytic loci by complexes. Read Oct. 31, 1931. Transactions of this Society, vol. 34, No. 2, pp. 231-251; April, 1932.

Buchanan, H. E. Small oscillations of the neutral helium atom near the equilateral triangle positions. Read Dec. 30,1930. American Mathematical Monthly, vol. 38, No.9, part 1, pp. 511-521; Nov., 1931.

Burington, R. S. An invariantive classification of plane cubic curves under the affine group. Read Sept. 10, 1931. Ohio State University, Graduate School, Abstracts of Doctors' Dissertations, No. 6, pp. 29-38; June, 1931.

Bush, L. E. Note on the discriminant matrix of an algebra. Read Nov. 28, 1931. This Bulletin, vol. 38, No. 2, pp. 49-51; Feb., 1932.

- On the equivalence of the decompositions of an algebra with respect to a principal idempotent. Read Nov. 28, 1931. American Journal of Mathematics, vol. 54, No. 2, pp. 419-424; April, 1932. 
Bush, V. The differential analyzer. A new machine for solving differential equations. Read Dec. 28, 1929. Journal of the Franklin Institute, vol. 212, No. 4, pp. 447-488; Oct., 1931.

- See Gray, T.S.

CAIRns, S. S. The cellular division and approximation of $n$-dimensional regions. Read June 20, 1930. Annals of Mathematics, (2), vol. 33, No. 4, pp. 671$680 ;$ Oct., 1932.

Campbell, A. D. Pencils of quadrics in the Galois fields of order $2^{n}$. Read Dec. 27, 1928. Tôhoku Mathematical Journal, vol. 34, No. 2, pp. 236-248; Aug., 1931.

- Apolarity in the Galois fields of order $2^{n}$. Read Dec. 28, 1931. This Bulletin, vol. 38, No. 2, pp. 52-56; Feb., 1932.

Carlitz, L. The arithmetic of polynomials in a Galois field. Read Dec. 30, 1930. American Journal of Mathematics, vol. 54, No. 1, pp. 39-50; Jan., 1932.

- Note on Diophantine automorphisms. Read Dec. 30, 1930. This Bulletin, vol. 38, No. 4, pp. 246-250; April, 1932.

- New Diophantine automorphisms. Read April 11, 1931. This Bulletin, vol. 38, No. 4, pp. 271-276; April, 1932.

- On arrays of numbers. Read Nov. 29, 1930. American Journal of Mathematics, vol. 54, No. 4, pp. 739-752; Oct., 1932.

- On polynomials in a Galois field. Read Aug. 31, 1932. This Bulletin, vol. 38, No. 10, pp. 736-744; Oct., 1932.

CARMICHAEL, R. D. Some recent researches in the theory of numbers. Read Dec. 31, 1931. American Mathematical Monthly, vol. 39, No. 3, pp. 139$162 ;$ March, 1932.

- Expansions of arithmetical functions in infinite series. Read Sept. 11, 1930. Proceedings of the London Mathematical Society, (2), vol. 34, No. 1, pp. 1-26; May, 1932.

- Note on triple systems. Read Sept. 2, 1932. This Bulletin, vol. 38, No. 10, pp. 695-696; Oct., 1932.

Carpenter, A. F. A triad of ruled surfaces defined by reciprocal polars. Read June 13, 1931. This Bulletin, vol. 38, No. 2, pp. 95-100; Feb., 1932.

Cauer, W. Über Funktionen mit positivem Realteil. Read Dec. 31, 1930. Mathematische Annalen, vol. 106, Nos. 2-3, pp. 369-394; March, 1932.

- The Poisson integral for functions with positive real part. Read Aug. 31, 1932. This Bulletin, vol. 38, No. 10, pp. 713-717; Oct., 1932.

Churchill, R. V. On the geometry of the Riemann tensor. Read Dec. 1, 1928. Transactions of this Society, vol. 34, No. 1, pp. 126-152; Jan., 1932.

- Canonical forms for symmetric linear vector functions in pseudo-euclidean space. Read Nov. 28, 1931. Transactions of this Society, vol. 34, No. 4, pp. 784-794; Oct., 1932.

Clarkson, J. M. Some involutorial line transformations interpreted as points of $V_{2}$ of $S_{5}$. Read March 26, 1932. This Bulletin, vol. 38, No. 8, pp. 533540; Aug., 1932.

CoE, C. J. Exterior motion in the restricted problem of three bodies. Read Nov. 29, 1929. Transactions of this Society, vol. 34, No. 4, pp. 811-837; Oct. 1932. 
Cohen, L. W. See Alexander, J. W.

Coleman, J. B. A coefficient of linear correlation based on the method of least squares and the line of best fit. Read Dec. 28, 1931. Annals of Mathematical Statistics, vol. 3, No. 2, pp. 79-85; May, 1932.

CraIG, A. T. On the distributions of certain statistics. Read Dec. 31, 1930. American Journal of Mathematics, vol. 54, No. 2, pp. 353-366; April, 1932. The simultaneous distribution of mean and standard deviation in small samples. Read Dec. 28, 1931. Annals of Mathematical Statistics, vol. 3, No. 2, pp. 126-140; May, 1932.

CraIG, C. C. On a property of the semi-invariants of Thiele. Read April 11, 1931. Annals of Mathematical Statistics, vol. 2, No. 2, pp. 154-164; May, 1931.

- Sampling in the case of correlated observations. Read April 11, 1931. Annals of Mathematical Statistics, vol. 2, No. 3, pp. 324-332; Aug., 1931. On the composition of dependent elementary errors. Read April 11, 1931. Annals of Mathematics, (2), vol. 33, No. 1, pp. 184-206; Jan., 1932.

Cramlet, C. M. A complete system of tensors of linear homogeneous secondorder differential equations. Read Dec. 30, 1930. Transactions of this Society, vol. 34, No. 3, pp. 626-644; July, 1932.

Cummings, L. D. Hexagonal systems of seven lines in a plane. Read Oct. 31, 1931. This Bulletin, vol. 38, No. 2, pp. 105-110; Feb., 1932.

- Heptagonal systems of eight lines in plane. Read March 26, 1932. This Bulletin, vol. 38, No. 10, pp. 700-702; Oct., 1932.

Currier, A. E. The variable end point problem of the calculus of variations including a generalization of the classical Jacobi conditions. Read April 9, 1932. Transactions of this Society, vol. 34, No. 3, pp. 689-704; July, 1932.

Curry, H. B. Some additions to the theory of combinators. Read Dec. 28, 1931. American Journal of Mathematics, vol. 54, No. 3, pp. 551-558; July, 1932.

Debely, N. See Bernstein, B. A.

DoDD, E. L. Frequency laws showing stability with reference to the geometric mean and other means. Read Dec. 28, 1931. This Bulletin, vol. 38, No. 6, pp. 398-402; June, 1932.

DooB, J. L. The boundary values of analytic functions. Read April 3, 1931. Transactions of this Society, vol. 34, No. 1, pp. 153-170; Jan., 1932.

Douglas, J. The problem of Plateau for two contours. Read Oct. 26, 1929, and Oct. 25, 1930. Journal of Mathematics and Physics of the Massachusetts Institute of Technology, vol. 10, No. 4, pp. 315-359; Dec., 1931; vol. 11, No. 2, p. 212; June, 1932.

- Systems of $K$-dimensional manifolds in an $N$-dimensional space. Read Dec. 27, 1928. Mathematische Annalen, vol. 105, No. 5, pp. 707-733; 1931.

Seven theorems in the problem of Plateau. Read Oct. 26, 1929, and Oct. 25, 1930. Proceedings of the National Academy of Sciences, vol. 18, No. 1, pp. 83-85; Jan., 1932.

_- One-sided minimal surfaces with a given boundary. Read Oct. 25, 1930. Transactions of this Society, vol. 34, No. 4, pp. 731-756; Oct., 1932. 
Dye, L. A., and Sharpe, F. R. The quartic space involutorial transformations with a double conic. Read Dec. 28, 1931. American Journal of Mathematics, vol. 54, No. 3, pp. 499-504; July, 1932.

EiesLand, J. The ruled $V_{n-1}^{n-1}$ in $S_{n}$. Second paper. Read Sept. 9, 1930. Tôhoku Mathematical Journal, vol. 35, No. 2, pp. 306-322; May, 1932.

Емсн, $\mathrm{A}$. The symmetric $(n, n)$-correspondence and some geometric applications. Read Nov. 28, 1931. American Journal of Mathematics, vol. 54, No. 2, pp. 285-292; April, 1932.

Evans, G. C. Complements of potential theory. Read Sept. 8, 1931. American Journal of Mathematics, vol. 54, No. 2, pp. 213-234; April, 1932.

- Note on the gradient of the Green's function. Read Aug. 31, 1932. This Bulletin, vol. 38, No. 12, pp. 879-886; Dec., 1932.

FELD, J. M. The generalized pedal transformation and birational contact transformations. Read April 3, 1931. (Dissertation, Columbia.) Hamburg, Lütcke and Wulff, 1931. 24 pp.

- The expansion of analytic functions in generalized Lambert series. Read June 20, 1930. Annals of Mathematics, (2), vol. 33, No. 1, pp. 139-142; Jan., 1932.

Foster, R. M. Geometrical circuits of electrical networks. Read Nov. 28, 1931. Transactions of the American Institute of Electrical Engineers, vol. 51, No. 2, pp. 309-317; June, 1932.

FrankLIN, P. Algebraic matric equations. Read Oct. 27, 1928. Journal of Mathematics and Physics of the Massachusetts Institute of Technology, vol. 10, No. 4, pp. 289-314; Dec., 1931.

Franklin, P., and Moore, C. L. E. Dual Pfaffians. Read Sept. 9, 1931. Journal of Mathematics and Physics of the Massachusetts Institute of Technology, vol. 11, No. 1, pp. 12-26; March, 1932.

Fulton, D. G., and Rainich, G. Y. Generalizations to higher dimensions of the Cauchy integral formula. Read Dec. 30, 1930. American Journal of Mathematics, vol. 54, No. 2, pp. 235-240; April, 1932.

Garabedian, H. L. Note on a theorem due to Bromwich. Read Aug. 31, 1932. This Bulletin, vol. 38, No. 8, pp. 541-544; Aug., 1932.

Garver, R. Determinants and the roots of an equation. Read April 11, 1931. Journal of the Indian Mathematical Society, vol. 19, No. 7, pp. 156-160; Feb., 1932.

- The evaluation of a certain type of property. Read Sept. 11, 1931. The Accounting Review, vol. 7, No. 1, pp. 70-74; March, 1932.

On the roots of a cubic and those of its derivative. Read Nov. 28, 1931. Mathematics News Letter (Baton Rouge, La.), vol. 6, Nos. 7-8, pp. 24-27; April-May, 1932.

- A note concerning a transformation on the Brioschi quintic. Read Sept. 9, 1931. Tohoku Mathematical Journal, vol. 35, No. 2, pp. 253-256; May, 1932.

- On the approximate solution of certain equations. Read March 25, 1932. American Mathematical Monthly, vol. 39, No. 8, pp. 476-478; Oct., 1932.

Gehman, H. M. Concerning sequences of homeomorphisms. Read Oct. 31, 1931. Proceedings of the National Academy of Sciences, vol. 18, No. 6, pp. 460-465; June, 1932.

Graustein, W. C. Parallelism and equidistance in classical differential geome- 
try. Read Nov. 28, 1931. Transactions of this Society, vol. 34, No. 3, pp. 557-593; July, 1932.

Graves, L. M. On the Weierstrass condition in the problem of Bolza in the calculus of variations. Read Sept. 9, 1931. Annals of Mathematics, (2), vol. 33, No. 4, pp. 747-752; Oct., 1932.

- On an existence theorem of the calculus of variations. Read April 3, 1931. Monatshefte für Mathematik und Physik, vol. 39, No. 1, pp. 101-104; 1932.

Gray, T. S. A photo-electric integraph. Read (by V. Bush) Dec. 28, 1929. Journal of the Franklin Institute, vol. 212, No. 1, pp. 77-102; July, 1931.

Groat, B. F. Fundamental error in theory of viscosity. Read Dec. 27, 1929. Journal of Engineering Education, vol. 22, No. 5, pp. 379-383; Jan., 1932.

Gronwall, T. H. Summation of series and conformal mapping. Read Oct. 31, 1925. Annals of Mathematics, (2), vol. 33, No. 1, pp. 101-117; Jan., 1932.

- An inequality for the Bessel functions of the first kind with imaginary argument. Read Sept. 9, 1931. Annals of Mathematics, (2), vol. 33, No. 2, pp. 275-278; April, 1932.

- A special conformally euclidean space of three dimensions occurring in wave mechanics. Read Sept. 11, 1931. Annals of Mathematics, (2), vol. 33, No. 2, pp. 279-293; April, 1932.

Hancock, H. Equivalent (quadratic) ideals have the same lattice points. Read Dec. 29, 1926. Foundations of the Theory of Algebraic Numbers, vol. I, article 289; New York, MacMillan, 1931.

HARry, C. H. An examination of some cut sets of space. Read Sept. 9, 1931. This Bulletin, vol. 38, No. 6, pp. 427-433; June, 1932.

Hasse, H. Theory of cyclic algebras over an algebraic number field. Read Sept. 9, 1931. Transactions of this Society, vol. 34, No. 1, pp. 171-214; Jan., 1932.

- Additional note to the author's "Theory of cyclic algebras over an algebraic number field." Read Sept. 9, 1931. Transactions of this Society, vol. 34, No. 3, pp. 727-730; July, 1932.

See Albert, A. A.

Hedlund, G. A. Poincaré's rotation number and Morse's type number. Read Sept. 11, 1930. Transactions of this Society, vol. 34, No. 1, pp. 75-97; Jan., 1932.

- Geodesics on a two-dimensional Riemannian manifold with periodic coefficients. Read Sept. 11, 1930. Annals of Mathematics, (2), vol. 33, No. 4, pp. 719-739; Oct., 1932.

Hickey, D. M. A three-dimensional treatment of groups of linear transformations. Read Dec. 27, 1928. American Journal of Mathematics, vol. 54, No. 4, pp. 635-647; Oct., 1932.

Hildebrandt, E. H. Systems of polynomials connected with the Charlier expansions and the Pearson differential and difference equations. Read Sept. 11, 1931. Annals of Mathematical Statistics, vol. 2, No. 4, pp. 379-439; Nov., 1931.

Hille, E. Summation of Fourier series. Read March 25, 1932. This Bulletin, vol. 38, No. 8, pp. 505-528; Aug., 1932.

Hille, E., and Tamarkin, J. D. On the summability of Fourier series. I. Read Sept. 7, 1928, and March 25, 1932. Transactions of this Society, vol. 34, No. 4, pp. 757-783; Oct., 1932. 
HollCroft, T. R. Hypersurfaces of order $n$ in $n$ dimensions. Read Dec. 27, 1928. Tôhoku Mathematical Journal, vol. 35, No. 1, pp. 1-7; Jan., 1932.

Hopf, E. On the time average theorems in dynamics. Read Dec. 28, 1931. Proceedings of the National Academy of Sciences, vol. 18, No. 1, pp. 93$100 ;$ Jan., 1932.

Theory of measure and invariant integrals. Read Sept. 11, 1931. Transactions of this Society, vol. 34, No. 2, pp. 373-393; April, 1932.

Horsfall, I. O. Transformations associated with the lines of a cubic, quadratic, or linear complex. Read Oct. 29, 1932. This Bulletin, vol. 38, No. 12, pp. 872-878; Dec., 1932.

HULL, R. The numbers of solutions of congruences involving only $k$ th powers. Read Aug. 31, 1932. Transactions of this Society, vol. 34, No. 4, pp. 908937; Oct., 1932.

Huntington, E. V. A new set of independent postulates for the algebra of logic with special reference to Whitehead and Russell's Principia Mathematica. Read Dec. 28, 1931. Proceedings of the National Academy of Sci. ences, vol. 18, No. 2, pp. 179-180; Feb., 1932.

Huntington, E. V., and Rosinger, K. E. Postulates for separation of pointpairs (reversible order on a closed line). Read April 11, 1925. Proceedings of the American Academy of Arts and Sciences, vol. 67, No. 4, pp. 61-145; March, 1932.

Hurwitz, W. A. Definition of a field by four postulates. Read March 26, 1932. Annals of Mathematics, (2), vol. 33, No. 3, pp. 403-405; July, 1932.

INGRAHAM, M. H. Note on the reducibility of algebras without a finite base. Read Dec. 31, 1928. This Bulletin, vol. 38, No. 2, pp. 100-104; Feb., 1932.

Jeffery, R. L. Relative summability. Read Sept. 9, 1930. Annals of Mathematics, (2), vol. 33, No. 3, pp. 443-459; July, 1932.

- Non-absolutely convergent integrals with respect to functions of bounded variation. Read April 9, 1932. Transactions of this Society, vol. 34, No. 3, pp. 645-675; July, 1932.

JonEs, B. W. On Selling's method of reduction for positive ternary quadratic forms. Read Sept. 9, 1931. American Journal of Mathematics, vol. 54, No. 1, pp. 14-34; Jan., 1932.

KASNER, E. Complex geometry and relativity: theory of the "rac" curvature. Read Oct. 31, 1931. Proceedings of the National Academy of Sciences, vol. 18, No. 3, pp. 267-274; March, 1932.

- General theorems in dynamics. Read March 25, 1932. Science, new ser., vol. 75, No. 1956, pp. 671-672; June 24, 1932.

- Geometry of the heat equation: First paper. Read Dec. 28, 1916. Proceedings of the National Academy of Sciences, vol. 18, No. 6, pp. 475-480; June, 1932.

Kennison, L. S. Reflections in function space. Read Feb. 28, 1931. This Bulletin, vol. 38, No. 2, pp. 131-134; Feb., 1932.

Keтchum, P. W. Solution of partial differential equations by means of hypervariables. Read March 29, 1929. American Journal of Mathematics, vol. 54, No. 2, pp. 253-264; April, 1932.

Kimball, B. F. Three theorems applicable to vibration theory. Read March 26, 1932. This Bulletin, vol. 38, No. 10, pp. 718-723; Oct., 1932. 
Kimball, W. S., and King, W. J. Theory of heat conduction and convection from a low hot vertical plate. Read April 3, 1931. Philosophical Magazine, (7), vol. 13, No. 87, pp. 888-906; May, 1932.

King, W. J. See Kimball, W. S.

Koopman, B. O. See Brown, A. B.

LANczos, C. Electricity as a natural property of Riemannian geometry. Read Nov. 28, 1931. Physical Review, (2), vol. 39, No. 4, pp. 716-736; Feb. $15,1932$.

LANE, E. P. Surfaces and curvilinear congruences. Read April 9, 1932. Transactions of this Society, vol. 34, No. 3, pp. 676-688; July, 1932.

LANGER, R. E. A problem in diffusion or in the flow of heat for a solid in contact with a fluid. Read Sept. 12, 1930. Tôhoku Mathematical Journal, vol. 35, No. 2, pp. 260-275; May, 1932.

- On the asymptotic solutions of differential equations with an application to the Bessel functions of large complex order. Read Sept. 9, 1931. Transactions of this Society, vol. 34, No. 3, pp. 447-480; July, 1932.

LAPAZ, L. Variation problems of which the extremals are minimal surfaces. Read Nov. 27, 1931. Acta Litterarum ac Scientiarum Regiae Universitatis Hungaricae Francisco-Josephinae, Szeged, vol. 5, Nos. 3-4, pp. 199-207; April, 1932.

LAWTON, W. S. On the zeros of certain polynomials related to Jacobi and Laguerre polynomials. Read March 26, 1932. This Bulletin, vol. 38, No. 6, pp. 442-448; June, 1932.

Lehmer, D. H. Arithmetic periodicities of Bessel functions. Read April 11, 1931. Annals of Mathematics, (2), vol. 33, No. 1, pp. 143-150; Jan., 1932.

- A ternary analogue of abelian groups. Read June 13,1931. American Journal of Mathematics, vol. 54, No. 2, pp. 329-338; April, 1932.

- Note on Mersenne numbers. Read April 2, 1927. This Bulletin, vol. 38, No. 6, pp. 383-384; June, 1932.

- Quasi-cyclotomic polynomials. Read Nov. 28, 1931. American Mathematical Monthly, vol. 39, No. 7, pp. 383-389; Aug.-Sept., 1932.

- An inversive algorithm. Read Aug. 31, 1932. This Bulletin, vol. 38, No. 10, pp. 693-694; Oct., 1932.

Levitzki, J. On normal products of algebras. Read April 3, 1931. Annals of Mathematics, (2), vol. 33, No. 3, pp. 377-402; July, 1932.

Littauer, S. B., and Seidel, W. Lines of Julia of integral functions. Read Oct. 31, 1931. Proceedings of the National Academy of Sciences, vol. 18, No. 1, pp. 90-93; Jan., 1932.

Lorch, E. R. Elementary transformations. Read March 26, 1932. Annals of Mathematics, (2), vol. 33, No. 2, pp. 214-228; April, 1932.

McCoy, N. H. On the resultant of three double binary forms. Read Feb. 28, 1931. Annals of Mathematics, (2), vol. 33, No. 1, pp. 177-183; Jan., 1932.

MCEwEn, W. H. On the approximate solution of linear differential equations with boundary conditions. Read Aug. 31, 1932. This Bulletin, vol. 38, No. 12, pp. 887-894; Dec., 1932.

McShane, E. J. On a certain inequality of Steiner. Read April 3, 1931. Annals of Mathematics, (2), vol. 33, No. 1, pp. 125-138; Jan., 1932.

- On the semi-continuity of double integrals in the calculus of variations. 
Read Dec. 30, 1931. Annals of Mathematics, (2), vol. 33, No. 3, pp. 460484 ; July, 1932.

MACDUfFEe, C. C. A method for determining the canonical basis of an ideal in an algebraic field. Read April 4, 1931. Mathematische Annalen, vol. 105, No. 5, pp. 663-665; Dec., 1931.

MacMillan, W. D. See Bartky, W.

MARCH, H. W., and TraYer, G. W. The torsion of members having sections common in aircraft construction. Read April 6, 1928. National Advisory Committee for Aeronautics, Report No. 334; 15th Annual Report, pp. 673$719 ; 1929$.

_ Elastic instability of members having sections common in aircraft construction. Read April 3, 1931. National Advisory Committee for Aeronautics, Report No. 382; 17th Annual Report, pp. 373-410; 1931.

MARDEN, M. A rule of signs involving certain orthogonal polynomials. Read Sept. 12, 1930. Annals of Mathematics, (2), vol. 33, No. 1, pp. 118-124; Jan., 1932.

- A generalization of Weierstrass' and Fekete's mean-value theorems. Read Dec. 30, 1931. This Bulletin, vol. 38, No. 6, pp. 434-441; June, 1932.

MARIA, A. J. Examples of harmonic functions. Read Sept. 10, 1931. This Bulletin, vol. 38, No. 12, pp. 839-843; Dec., 1932.

MENGE, W. O. On the rank of the product of certain square matrices. Read Dec. 30, 1930. This Bulletin, vol. 38, No. 2, pp. 88-94; Feb., 1932.

MeYer, H. A. On certain inequalities with applications in actuarial theory. Read Dec. 30, 1929. Giornale di Matematica Finanziaria, (2), vol. 1, Nos. 2-5, pp. 122-130; Feb.-Oct., 1931.

Michal, A. D. See Botsford, J. L.

Miller, E. W. On subsets of a continuous curve which lie on an arc of the continuous curve. Read Nov. 30, 1928, and April 19, 1930. American Journal of Mathematics, vol. 54, No. 2, pp. 397-416; April, 1932.

- Solution of the Zarankiewicz problem. Read Oct. 29, 1932. This Bulletin, vol. 38, No. 12, pp. 831-834; Dec., 1932.

Miller, N. Some extensions of the Schwarz-Stieltjes theorem of mean value and some consequences deduced therefrom. Read Sept. 9, 1931. Transactions of the Royal Society of Canada, (3), vol. 25, section 3, pp. 195-204; May, 1931.

Mitchell, A. K. On a matrix differential operator. Read March 26, 1932. This Bulletin, vol. 38, No. 4, pp. 251-258; April, 1932.

Moore, C. L. E. See Franklin, P.

Moore, C. N. On certain criteria for Fourier constants of $L$ integrable functions. Read Sept. 9, 1931, and March 25, 1932. Proceedings of the National Academy of Sciences, vol. 18, No. 5, pp. 396-399; May, 1932.

Moore, R. L. Foundations of point set theory. Read Aug. 27-30, 1929. American Mathematical Society Colloquium Publications, vol. 13; 1932. $8+486 \mathrm{pp}$.

Moritz, R. E. A new theory of depreciation of physical assets. Read June 13, 1931. Annals of Mathematical Statistics, vol. 3, No. 2, pp. 108-125; May, 1932.

Nathan, D. S. See Barnett, I. A. 
Neelley, J. H. Concerning the possibility of certain binary quartics being line sections of the plane quartic curve of genus zero and the complete system of independent forms of two binary quartics. Read Sept. 9, 1930, and Dec. 30, 1930. Tôhoku Mathematical Journal, vol. 35, No. 1, pp. 51-59; Jan., 1932.

Nelson, C. A. On surfaces possessing a net of plane isothermally-conjugate curves. Read Dec. 27, 1928. American Journal of Mathematics, vol. 54, No. 2, pp. 314-328; April, 1932.

Oldenburger, R. On canonical binary trilinear forms. Read April 9, 1932. This Bulletin, vol. 38, No. 6, pp. 385-387; June, 1932.

Olds, E. G. The nature of distributions in small samples. Read Dec. 31, 1930. University of Pittsburgh Bulletin, vol. 28, No. 4, pp. 134-144; Dec., 1931.

ORE, O. Formale Theorie der linearen Differentialgleichungen. (Erster und Zweiter Teil.) Read Oct. 31, 1931. Journal für Mathematik, vol. 167, pp. 221-234; 1932; vol. 168, No. 4, pp. 233-252; Dec., 1932.

PALL, G. Large positive integers are sums of four or five values of a quadratic function. Read Nov. 29, 1930. American Journal of Mathematics, vol. 54, No. 1, pp. 66-78; Jan., 1932.

- On sums of two or four values of a quadratic function of $x$. Read Nov. 29, 1930. Transactions of this Society, vol. 34, No. 1, pp. 98-125; Jan., 1932.

- A class of universal functions. Read Dec. 28, 1931. This Bulletin, vol. 38, No. 2, pp. 56-58; Feb., 1932.

Paradiso, L. J. Solutions of bounded variation of the Fredholm-Stieltjes integral equation. Read Dec. 31, 1930. This Bulletin, vol. 38, No. 4, pp. 255258; April, 1932.

Parkinson, G. A. Pairs of curves in an $S_{n}$. Read Nov. 29, 1929. Annals of Mathematics, (2), vol. 33, No. 4, pp. 649-657; Oct., 1932.

Pennell, W. O. Fourier series in three dimensions. Read Feb. 28, 1931. American Mathematical Monthly, vol. 39, No. 5, pp. 261-266; May, 1932.

Poritsky, H. On certain polynomial and other approximations to analytic functions. Read Aug. 29, 1929, and Dec. 27, 1929. Transactions of this Society, vol. 34, No. 2, pp. 274-331; April, 1932.

RADÓ, T. Contributions to the theory of minimal surfaces. Read Sept. 11, 1931, and April 8, 1932. Acta Litterarum ac Scientiarum Regiae Universitatis Hungaricae Francisco-Josephinae, Szeged, vol. 6, No. 1, pp. 1-20; Sept., 1932.

Rainich, G. Y. See Fulton, D. G.

RAwles, T. H. A note on hypergeometric functions of two variables. Read Dec. 30, 1930. Annals of Mathematics, (2), vol. 33, No. 1, pp. 151-155; Jan., 1932.

REID, W. T. A boundary value problem associated with the calculus of variations. Read Sept. 9, 1931. American Journal of Mathematics, vol. 54, No. 4, pp. 769-790; Oct., 1932.

- On boundary value problems associated with double integrals in the calculus of variations. Read Dec. 31, 1930. American Journal of Mathematics, vol. 54, No. 4, pp. 791-801; Oct., 1932.

Reynolds, C. N. Circuits upon polyhedra. Read Sept. 9, 1930. Annals of Mathematics, (2), vol. 33, No. 2, pp. 367-372; April, 1932. 
Rietz, H. L. On the Lexis theory and the analysis of variance. Read Dec. 28, 1931. This Bulletin, vol. 38, No. 10, pp. 731-735; Oct., 1931.

Ritr, J. F. Differential equations from the algebraic standpoint. Read Feb. 28, 1931, and Aug. 30-Sept. 2, 1932. American Mathematical Society Colloquium Publications, vol. $14 ; 1932.10+172 \mathrm{pp}$.

Roberts, J. H. Concerning topological transformations in $E_{n}$. Read June 2, 1928, and Nov. 28, 1930. Transactions of this Society, vol. 34, No. 2, pp. 252-262; April, 1932.

- Concerning uniordered spaces. Read March 25, 1932. Proceedings of the National Academy of Sciences, vol. 18, No. 5, pp. 403-406; May, 1932.

- A property related to completeness. Read April 11, 1931. This Bulletin, vol. 38, No. 12, pp. 835-838; Dec., 1932.

- A point set characterization of closed 2-dimensional manifolds. Read Dec. 27, 1929, and Feb. 22, 1930. Fundamenta Mathematicae, vol. 18, pp. 39-46; 1932.

Robertson, H. P. Groups of motions in spaces admitting absolute parallelism. Read Dec. 30, 1930. Annals of Mathematics, (2), vol. 33, No. 3, pp. 496520 ; July, 1932.

Rosinger, K. E. See Huntington, E. V.

Rотн, W. E. On algebraic equations having only real roots. Read Nov. 28, 1931. This Bulletin, vol. 38, No. 8, pp. 594-600; Aug., 1932.

RUsT, W. M. Integral equations and the cooling problem for several media. Read June 13, 1931. American Journal of Mathematics, vol. 54, No. 1, pp. 190-212; Jan., 1932.

RutLedGe, G. The inverse matrix for de la Vallée-Poussin summation. Read March 25, 1932. Journal of Mathematics and Physics of the Massachusetts Institute of Technology, vol. 11, No. 1, pp. 73-82; March, 1932.

SCHLAUCH, H. M. Mixed systems of linear equations and inequalities. Read Dec. 27, 1929. American Mathematical Monthly, vol. 39, No. 4, pp. 218222; April, 1932.

SchoenberG, I. J. On finite and infinite completely monotonic sequences. Read Nov. 28, 1931. This Bulletin, vol. 38, No. 2, pp. 72-76; Feb., 1932.

- Some applications of the calculus of variations to Riemannian geometry. Read June 13, 1931. Annals of Mathematics, (2), vol. 33, No. 3, pp. 485495; July, 1932.

- On finite-rowed systems of linear inequalities in infinitely many variables. Read Dec. 30, 1931. Transactions of this Society, vol. 34, No. 3, pp. 594619; July, 1932.

See BLISS, G. A.

Schoonmaker, H. E., and Snyder, V. Two involutorial transformations, of orders 11 and 9, associated with null reciprocities. Read Dec. 28, 1931. American Journal of Mathematics, vol. 54, No. 2, pp. 299-304; April, 1932.

SEIDEL, W. On the cluster values of analytic functions. Read Dec. 30, 1930, and April 3, 1931. Transactions of this Society, vol. 34, No. 1, pp. 1-21; Jan., 1932.

- See Littauer, S. B.

Sharpe, F. R. See Dye, L. A. 
Sherman, J., and Shohat, J. On the numerators of the continued fraction $\frac{\lambda_{1} \mid}{\mid x-c_{1}}-\frac{\lambda_{2} \mid}{\mid x-c_{2}}-\cdots \cdot$ Read March 26, 1932. Proceedings of the National Academy of Sciences, vol. 18, No. 3, pp. 283-287; March, 1932.

Sнонат, J. On Stieltjes continued fractions. Read Sept. 9, 1931. American Journal of Mathematics, vol. 54, No. 1, pp. 79-84; Jan., 1932. See Sherman, J.

Simmons, H. A. Maximum numbers associated with the Diophantine equation $\sum\left(1 / x_{1} x_{2} \cdots x_{n-1}\right)=b[(m+1) b-1]$. Read April 16, 1927. American Mathematical Monthly, vol. 37, No. 3, pp. 137-142; March, 1930.

- Classes of maximum numbers and minimum numbers that are associated with certain symmetric equations in $n$ reciprocals. Read April 4, 1931, Dec. 28, 1931, and April 9, 1932. Transactions of this Society, vol. 34, No. 4, pp. 876-907; Oct., 1932.

Smith, P. A. Properties of group manifolds. Read Oct. 31, 1931. Proceedings of the National Academy of Sciences, vol. 17, No. 12, pp. 674-675; Dec., 1931.

Snyder, V. See Schoonmaker, H. E.

Stelson, H. E. Double function space. Read Dec. 30, 1930. Tôhoku Mathematical Journal, vol. 34, No. 2, pp. 297-320; Aug., 1931.

Stephens, R. Continuous transformations of abstract spaces. Read Dec. 28, 1931. Transactions of this Society, vol. 34, No. 2, pp. 394-408; April, 1932.

Stone, M. H. On one-parameter unitary groups in Hilbert space. Read Oct. 25, 1930. Annals of Mathematics, (2), vol. 33, No. 3, pp. 643-648; July, 1932.

Stouffer, E. B. A geometrical determination of the canonical quadric of Wilczynski. Read April 9, 1932. Proceedings of the National Academy of Sciences, vol. 18, No. 3, pp. 252-255; March, 1932.

- On the contact of two space curves. Read April 9, 1932. This Bulletin, vol. 38, No. 6, pp. 415-419; June, 1932.

Swingle, P. M. Biconnected and related sets. Read Dec. 31, 1930. American Journal of Mathematics, vol. 54, No. 3, pp. 525-535; July, 1932.

Synge, J. L. The apsides of general dynamical systems. Read Dec. 28, 1931. Transactions of this Society, vol. 34, No. 3, pp. 481-522; July, 1932.

Tamarkin, J. D. On a theorem of S. Bernstein-Widder. Read Sept. 9, 1931. Transactions of this Society, vol. 33, No. 4, pp. 893-896; Oct., 1931.

- On the compactness of the space $L_{p}$. Read Oct. 31, 1931. This Bulletin, vol. 38, No. 2, pp. 79-84; Feb., 1932.

- See Hille, E.

Thomas, J. M. The condition for an orthonomic differential system. Read Oct. 31, 1931. Transactions of this Society, vol. 34, No. 2, pp. 332-338; April, 1932.

Trayer, G. W. See March, H. W.

TrJitzinsky, W. J. A synthesis of the theorems of Hadamard and Hurwitz on composition of singularities. Read Dec. 30, 1930. Proceedings of the National Academy of Sciences, vol. 17, No. 10, pp. 568-570; Oct., 1931.

VANDIVER, H. S. On the norm-residue symbol in the theory of cyclotomic 
fields. Read Sept. 9, 1931. Proceedings of the National Academy of Sciences, vol. 16, No. 11, pp. 740-743; Nov., 1930.

On the second factor of the class number of a cyclotomic field. Read Sept. 9, 1931. Proceedings of the National Academy of Sciences, vol. 16, No. 11, pp. 743-749; Nov., 1930.

- Summary of results and proofs on Fermat's last theorem (sixth paper). Read Sept. 9, 1931. Proceedings of the National Academy of Sciences, vol. 17, No. 12, pp. 661-673; Dec., 1931.

- On the method of infinite descent in connection with Fermat's last theorem for regular prime exponents. Read Sept. 9, 1931. Commentarii Mathematici Helvetici, vol. 4, pp. 1-8; 1932.

Walker, E. A study of the Traité des Indivisibles of Gilles Persone de Roberval. Read Jan. 1, 1926. Teachers College, Columbia University, Contributions to Education, No. $446 ; 1932.6+272 \mathrm{pp}$.

Wall, H. S. On the expansion of an integral of Stieltjes. Read March 29, 1929. American Mathematical Monthly, vol. 39, No. 2, pp. 96-108; Feb., 1932.

- General theorems on the convergence of sequences of Padé approximants. Read April 3, 1931. Transactions of this Society, vol. 34, No. 2, pp. 409416; April, 1932.

- On the relationship among the diagonal files of a Padé table. Read Sept. 12, 1930. This Bulletin, vol. 38, No. 10, pp. 752-760; Oct., 1932.

WALSH, J. L. On the overconvergence of certain sequences of rational functions of best approximation. Read Oct. 31, 1931. Acta Mathematica, vol. 57, Nos. 3-4, pp. 411-435; 1931.

- On interpolation and approximation by rational functions with preassigned poles. Read Feb. 28, 1931. Transactions of this Society, vol. 34, No. 1, pp. 22-74; Jan., 1932.

- An expansion of meromorphic functions. Read March 25, 1932. Proceedings of the National Academy of Sciences, vol. 18, No. 2, pp. 165-171; Feb., 1932.

- On polynomial interpolation to analytic functions with singularities. Read March 25, 1932. This Bulletin, vol. 38, No. 4, pp. 289-294; April, 1932.

- On the overconvergence of sequences of rational functions. Read March 25, 1932. American Journal of Mathematics, vol. 54, No. 3, pp. 559-570; July, 1932.

- Interpolation and functions analytic interior to the unit circle. Read March 25, 1932. Transactions of this Society, vol. 34, No. 3, pp. 523-556; July, 1932 .

WARD, L. E. A third-order irregular boundary value problem and the associated series. Read Oct. 31, 1931. Transactions of this Society, vol. 34, No. 2, pp. 417-434; April, 1932.

WARD, M. The linear form of numbers represented by a homogeneous polynomial in any number of variables. Read April 11, 1931. Annals of Mathematics, (2), vol. 33, No. 2, pp. 324-326; April, 1932.

Wertheimer, A. A generalized error function. Read Dec. 28, 1931. Annals of Mathematical Statistics, vol. 3, No. 1, pp. 64-77; Feb., 1932. 
White, H. S. The plane figure of seven real lines. Read Oct. 31, 1931. This Bulletin, vol. 38, No. 2, pp. 59-65; Feb., 1932.

Whitney, H. Congruent graphs and the connectivity of graphs. Read Feb. 28, 1931. American Journal of Mathematics, vol. 54, No. 1, pp. 150-168; Jan., 1932.

- Note on Perron's solution of the Dirichlet problem. Read Dec. 30, 1931. Proceedings of the National Academy of Sciences, vol. 18, No. 1, pp. 68-70; Jan., 1932.

- Regular families of curves. I. Read March 25, 1932. Proceedings of the National Academy of Sciences, vol. 18, No. 3, pp. 275-278; March, 1932.

- Regular families of curves. II. Read March 25, 1932. Proceedings of the National Academy of Sciences, vol. 18, No. 4, pp. 340-342; April, 1932.

- Non-separable and planar graphs. Read Oct. 25, 1930. Transactions of this Society, vol. 34, No. 2, pp. 339-362; April, 1932.

- A logical expansion in mathematics. Read Oct. 25, 1930. This Bulletin, vol. 38, No. 8, pp. 572-579; Aug., 1932.

- The coloring of graphs. Read Oct. 25, 1930. Annals of Mathematics, (2), vol. 33, No. 4, pp. 688-718; Oct., 1932.

Whyburn, G. T. On the decomposability of closed sets into a countable number of simple sets of various types. Read Dec. 28, 1931. American Journal of Mathematics, vol. 54, No. 1, pp. 169-175; Jan., 1932.

- A certain transformation on metric spaces. Read March 25, 1932. American Journal of Mathematics, vol. 54, No. 2, pp. 367-376; April, 1932.

- On the construction of simple arcs. Read Sept. 9, 1931. American Journal of Mathematics, vol. 54, No. 3, pp. 518-524; July, 1932.

- A note on spaces having the $S$ property. Read Sept. 11, 1931. American Journal of Mathematics, vol. 54, No. 3, pp. 536-538; July, 1932.

- Concerning the proposition that every closed, compact, and totally disconnected set of points is a subset of an arc. Read Sept. 9, 1930. Fundamenta Mathematicae, vol. 18, pp. 47-60; 1932.

Whyвurn, W. M. On the integration of unbounded functions. Read Nov. 28, 1931. This Bulletin, vol. 38, No. 2, pp. 122-131; Feb., 1932.

Wiener, N. Tauberian theorems. Read Oct. 27, 1928. Annals of Mathematics, (2), vol. 33, No. 1, pp. 1-100; Jan., 1932.

WILDER, R. L. A plane, arcwise connected and connected im kleinen point set which is not strongly connected im kleinen. Read Dec. 31, 1930. This Bulletin, vol. 38, No. 8, pp. 531-532; Aug., 1932.

- Point sets in three and higher dimensions and their investigation by means of a unified analysis situs. Read April 8, 1932. This Bulletin, vol. 38, No. 10, pp. 649-692; Oct., 1932.

- On the imbedding of subsets of a metric space in Jordan continua. Read March 29, 1929. Fundamenta Mathematicae, vol. 19, pp. 45-64; 1932.

WILKs, S. S. On the distribution of statistics in samples from a normal population of two variables with matched sampling of one variable. Read April 3, 1931. Metron, vol. 9, Nos. 3-4, pp. 87-126; March, 1932.

Williams, A. R. The transformation of lines of space effected by means of two quadratic reguli. Read Nov. 28, 1931. This Bulletin, vol. 38 , No. 8, pp. 554-559; Aug., 1932. 
WILson, W. A. On upper semi-continuous decompositions of compact continua. Read Sept. 9, 1931. American Journal of Mathematncs, vol. 54, No. 2, pp. 377-386; April, 1932.

- On cyclic numbers of one-dimensional compact sets. Read Sept. 9, 1931. Transactions of this Society, vol. 34, No. 2, pp. 263-273; April, 1932.

- A relation between metric and euclidean spaces. Read March 25, 1932. American Journal of Mathematics, vol. 54, No. 3, pp. 505-517; July, 1932.

- On angles in certain metric spaces. Read March 25, 1932. This Bulletin, vol. 38, No. 8, pp. 580-588; Aug., 1932.

Yerushalmy, J. On the representative space $S_{9}$ of the plane cubics. Read April 4, 1931. American Journal of Mathematics, vol. 54, No. 1, pp. 129-144; Jan., 1932.

ZARISKI, O. On the topology of algebroid singularities. Read March 25, 1932. American Journal of Mathematics, vol. 54, No. 3, pp. 453-470; July, 1932.

ZipPIN, L. Generalization of a theorem due to C. M. Cleveland. Read June 21, 1929, and April 11, 1931. American Journal of Mathematics, vol. 54, No. 1, pp. 176-184; Jan., 1932.

- The Moore-Kline problem. Read June 13, 1931. Transactions of this Society, vol. 34, No. 3, pp. 705-721; July, 1932.

Zygmund, A. On lacunary trigonometric series. Read March 25, 1932. Transactions of this Society, vol. 34, No. 3, pp. 435-446; July, 1932. 